\title{
Current affairs on TikTok. Virality and entertainment for digital natives
}

\author{
Simón Peña-Fernández; Ainara Larrondo-Ureta; Jordi Morales-i-Gras
}

Nota: Este artículo se puede leer en español en:

https://revista.profesionaldelainformacion.com/index.php/EPI/article/view/86803

How to cite this article:

Peña-Fernández, Simón; Larrondo-Ureta, Ainara; Morales-i-Gras, Jordi (2022). "Current affairs on TikTok. Virality and entertainment for digital natives". Profesional de la información, v. 31, n. 1, e310106.

https://doi.org/10.3145/epi.2022.ene.06

Article received on December $13^{\text {th }}, 2021$ Approved on December $26^{\text {th }}, 2021$

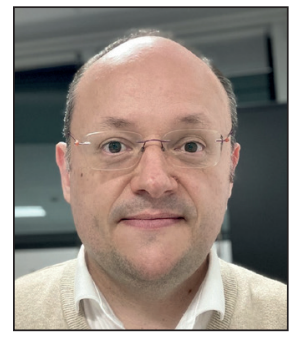

Simón Peña-Fernández $\triangle$ https://orcid.org/0000-0003-2080-3241

Universidad del País Vasco (UPV/EHU)

Facultad de Ciencias Sociales y de la

Comunicación

Barrio Sarriena, $\mathrm{s} / \mathrm{n}$

48940 Leioa (Vizcaya), Spain

simon.pena@ehu.eus

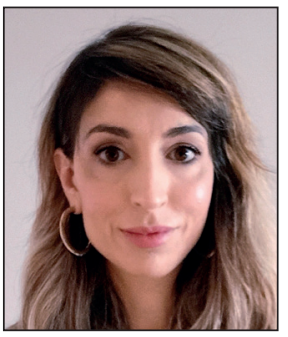

Ainara Larrondo-Ureta

https://orcid.org/0000-0003-3303-4330

Universidad del País Vasco (UPV/EHU)

Facultad de Ciencias Sociales y de la

Comunicación

Barrio Sarriena, $\mathrm{s} / \mathrm{n}$

48940 Leioa (Vizcaya), Spain

ainara.larrondo@ehu.eus

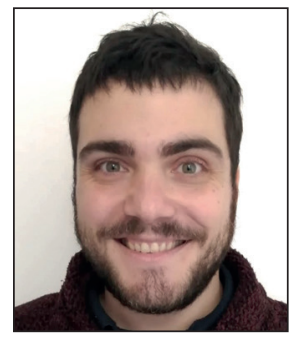

Jordi Morales-i-Gras

https://orcid.org/0000-0003-4173-3609

Universidad del País Vasco (UPV/EHU)

Facultad de Ciencias Sociales y de la

Comunicación

Barrio Sarriena, $\mathrm{s} / \mathrm{n}$

48940 Leioa (Vizcaya), Spain

morales.jordi@gmail.com

\begin{abstract}
Since its appearance in 2018, TikTok has become one of the most popular social media platforms among digital natives because of its algorithm-based engagement strategies, a policy of public accounts, and a simple, colorful, and intuitive content interface. As happened in the past with other platforms such as Facebook, Twitter, and Instagram, various media are currently seeking ways to adapt to TikTok and its particular characteristics to attract a younger audience less accustomed to the consumption of journalistic material. Against this background, the aim of this study is to identify the presence of the media and journalists on TikTok, measure the virality and engagement of the content they generate, describe the communities created around them, and identify the presence of journalistic use of these accounts. For this, 23,174 videos from 143 accounts belonging to media from 25 countries were analyzed. The results indicate that, in general, the presence and impact of the media in this social network are low and that most of their content is oriented towards the creation of user communities based on viral content and entertainment. However, albeit with a lesser presence, one can also identify accounts and messages that adapt their content to the specific characteristics of TikTok. Their virality and engagement figures illustrate that there is indeed a niche for current affairs on this social network.
\end{abstract}

\section{Keywords}

TikTok; Virality; Entertainment; Journalism; Media; Journalists; Social networks; Social media; Engagement; Digital natives; News; Information.

\section{Funding}

This work is part of the project "Noticias, redes y usuarios en el sistema híbrido de medios" (RTI2018-095775B-C41), financed by Plan Nacional del I+D+i, of the Spanish Ministerio de Ciencia, Innovación y Universidades and by European Regional Development Fund (ERDF), and by Grupo de Investigación del Gobierno Vasco "Gureiker" (IT 1112). 


\section{Introduction}

The constant change and adaptation symbolized by the innovation paradigm are hallmarks of the social communication and journalism that are taught, researched, and practiced in the second decade of the twenty-first century. Various prior works have reiterated the constant change currently seen in journalism, especially since the emergence of digital and web technology (Wu; Tandoc; Salmon, 2019). Since the birth of the web, this development has been examined in studies focused on the narratives and content of digital media, including both the web versions of reference journalistic media and the media platforms that emerged in the heat of the so-called social web (Peña-Fernández; Lazkano-Arrillaga; García-González, 2016).

In this regard, the most recent contributions regarding the impact and implications of interactive narratives have focused their interest on those media with a majority native digital audience, specifically the so-called centennials or young people belonging to Generation Z, born from the middle of the 1990s to the early 2000s. These young audiences tend to consume news via mobile devices, considering it to be part of a whole or a constant and broader flow of content (Boczkowski; Mitchelstein; Matassi, 2018; Vector ITC, 2020). In general, in recent years, various works and studies have reported a general interest from all types of audiences in obtaining news information through social media (Shearer, 2018; Wang; Gu; Wang, 2019; Pew Research Center, 2021).

This type of consumption is represented by social platforms such as YouTube, Facebook, and Instagram, as well as other more recent ones, among which TikTok stands out. In this context, the media continue to experiment and innovate to adapt to the communicative logic of social platforms and be able to compete (or even survive) in a multi-broadcaster sector (Rashidian et al., 2020).

TikTok emerged in 2018 from the merger of the services Douyin and Musical.Ly (Anderson, 2020) and has since become one of the most prominent social media platforms, being one of the applications preferred by the public aged 10-29 years, which represents $63.5 \%$ of users in countries such as the USA, where this platform reached 45.6 million active users in 2020 (Statista, 2020). In fact, coinciding with the global pandemic situation during the first quarter of 2020, this network was the second most downloaded social platform (Argintzona, 2020; Vector ITC, 2020). According to data from January 2021, TikTok was ranked as the seventh social network in terms of worldwide users, ahead of platforms such as Twitter, Telegram, and Snapchat (Statista, 2021). By February 2021 TikTok surpassed one hundred million active monthly users.

The communicative features of TikTok are linked to the possibilities of generating greater engagement and interest in audiences through consumer experiences that embrace both the concrete (content, information, etc.) and abstract (personal narrative or storytelling, emotionality, etc.). Thanks to its policy of public accounts and a simple, colorful, and intuitive content interface, TikTok enables quick consumption and viewing of light-hearted videos. In general, it shares its main communicative features with other social platforms (Klinger, 2013): the possibility of sharing, categorizing, and viralization through tags or hashtags, searching, positioning through "likes," audiovisualization, entertainment, etc.

Notwithstanding, TikTok's engagement strategies are somewhat more sophisticated, being based on the use of algorithms (artificial intelligence). This has led the network to launch personalized consumption offerings based on analysis of the content with the greatest changes of generating "likes," comments, and views (Wang; Gu; Wang, 2019; Anderson, 2020). Unlike other social networks, the user selects this content in response to instant or intuitive decisions made live, rather than decisions based on recommendations from contacts (Asarch, 2018). TikTok thereby achieves a wider and more diverse audience than social media networks with the traditional, follower-based model.

The communicative experience promoted by TikTok fits well in the current context marked by the so-called affective turn in the social sciences (Wahl-Jorgensen, 2020). However, academic literature on the use of this platform has a limited track record. Studies published to date have focused on the so-called \#challenges facing users, who are encouraged to create videos on certain topics (Alexander, 2019; Ahlse; Nilsson; Sandström, 2020; Sánchez-Castillo; Mercado-Sáez, 2021). In this regard, it is worth highlighting some studies related to health communication and, specifically, information generated in relation to Covid-19 (Ostrovsky; Chen, 2020; Sidorenko-Bautista; Herranz-de-la-Casa; Cantero-de-Julián, 2020), as well as political information (Medina-Serrano; Papakyriakopoulos; Hegelich, 2020; Cervi; Marín-Lladó, 2021) and advertising (Han, 2020).

The influence of TikTok has been felt in different social and cultural spheres (Herrman, 2019), so it is logical to consider that journalism will also be affected by this creative and distribution offering. As happened in the past with other platforms such as Facebook, Twitter, and Instagram, various media are currently looking for a way to adapt to TikTok using formulas different from those already used and known in social media. This adaptation is part of a strategy of innovation and continuous evolution of communication companies, although it has particular characteristics, given that it responds to very specific actions to attract the youngest audience that is less accustomed to the consumption of journalistic material.

In this sense and considering the above-mentioned characteristics of TikTok, it is interesting to analyze how the main media around the world have transferred their news activity to this social media platform. In fact, TikTok already exhibits innovative and creative practices that seem to represent an evolution, providing a new basis for an analysis and reflection on journalism as a concept and social practice. 


\section{State of the art}

For more than a decade, various studies have reported on the development of a specific journalistic paradigm based on the expansion of the main social media brands on social networks, as well as the creation of specially adapted content to promote the integration of styles and narratives (Welbers; Opgenhaffen, 2019; Klinger, 2013). In this regard, one should highlight some recent works on the adaptation of content for Twitter (García-Avilés; Arias-Robles, 2016), WhatsApp and Telegram (Negreira-Rey; López-García; Lozano-Aguiar, 2017; Dodds, 2019; Boczek; Koppers, 2020), and Instagram (Vázquez-Herrero; Direito-Rebollal; López-García, 2019).

In terms of practice and routines as well as product messages, the profession is affected by different communication scenarios that are dependent on the various social networks that appear. This has been defined as "networked journalism," which necessarily implies a consideration of the impact of social networks (Hermida, 2016; Pavlik, 2019; Zelizer, 2019).

Among the specific analyses regarding journalistic information on TikTok, the study by Vázquez-Herrero, Negreira-Rey, and López-García (2020) should be highlighted. According to that work, the studied media adapted to the logic of TikTok with a journalistic aim, which opened up new possibilities for the profession and responded to the objectives of journalistic companies: to report differently and position the brand. Likewise, Zaffarano's interesting study from the middle of 2020 listed a total of 270 organizations, many of which have already begun to search for specialists on TikTok. Among them, The Washington Post has been one of the pioneering brands (Zaffarano, 2021). In view of this potential, the study by Henneman (2020) focused on the incorporation of TikTok as a tool for university education on journalism.

Considering the characteristics of journalistic narratives on TikTok and taking into account that higher levels of engagement imply more attentive and receptive audiences (Valerio et al., 2015), recent analyses have focused on blurring the boundaries between information and entertainment as well as the direct influence of interactions on information. Beyond the tensions between traditional journalism and change, the media have also responded to the rise of TikTok since 2019 with different strategies and becoming subject to the dynamics of this platform, constructing new ways of bringing journalism closer to audiences (Vázquez-Herrero; Negreira-Rey; López-García, 2020).

Undoubtedly, technological advance has occurred alongside the concept of constant change in the field of social communication and journalism, along with other characteristic features of digitized communication content, such as hybridity (Chadwick, 2013). Meanwhile, multiplatform media (Rashidian et al., 2020) offer new opportunities to produce and disseminate traditional messages (Spyridou et al., 2013; Bell; Owen, 2017).

Thanks to mobile technology, the nexus of different types of platforms has contributed to the transfer of journalistic information to channels beyond traditional media (Rashidian et al., 2020; Carlson, 2020), and it is these very media that are now attempting to position themselves in these spaces. All of this highlights the tensions that emerge because of the shift from traditional to digital journalism (Eldridge et al., 2019; Wu; Tandoc; Salmon, 2019).

News stopped being a prerogative of the mainstream media several years ago. Authors such as Steensen and Westlund (2020) refer to various interdependent factors, such as the loss of trust in or reliability of this type of media and the difficulties in both implementing innovations at different levels and addressing audiences with different information consumption cultures. Not surprisingly, younger audiences show less interest in conducting active searches for journalistic content (Sveningsson, 2015; Boczkowski; Mitchelstein; Matassi, 2018) while also showing a greater preference for entertainment content.

In short, for more than a decade, social media platforms have provided a spur for conventional media brands, which seek to develop current affairs formulas adapted to these channels. Almost 20 years ago, social networks such as YouTube, Facebook, and Twitter introduced significant changes in how the major press, radio, and television brands generated and distributed content. With the successive emergence of further social media platforms such as Instagram, social communication studies have delved into the consequences for journalism as a discipline and profession, indicating changes in paradigm, goals, and values. As they are not accustomed to consuming news, the youngest audiences tend to do so in a little planned or premeditated way today. Such consumption is not sought but somewhat accidental, not being limited by loyalty toward certain brands (Ahmadi; Wohn, 2018; Sveningsson, 2015).

For all these reasons, TikTok stands out among recent social platforms because of its nature as a "creative medium" on which messages are oriented towards entertainment (Anderson, 2020; BBC, 2020). The journalistic narratives disseminated on TikTok thus seem to represent "entertainment journalism" (Labio-Bernal, 2008) that responds well to the philosophy of fast consumption of content, or so-called fast content (Ballesteros-Herencia, 2020).

In this context, the objective of this study is to investigate how the media uses TikTok to connect with younger audiences. Based on these challenges and the research opportunities that TikTok offers in the communication field, this study focuses on audiovisual narratives of a journalistic nature. To do so, we study the general presence of the media on TikTok (RQ1) and the virality and engagement achieved by the content they generate (RQ2). Based on these data, we then analyze the characteristics of the follower communities created around the content generated by media and journalists (RQ3) and the specific following of current affairs content (RQ4). 


\section{Methodology}

To analyze the current affairs content created by media and journalists on TikTok, we start from the catalog prepared by Zaffarano (2021), which includes 271 accounts that publish current affairs information in 25 countries. Among these, the 143 accounts belonging to media (120) or journalists (23) were selected. In these cases, the metadata associated with each user was processed, including biography, number of followers, number of "likes," and the language of the publications (RQ1).

For the empirical analysis, the usual variables applied to measure the engagement and viralization of messages were used. The data were captured using web scrapping techniques with the help of BrightData, which supplied between 30 and 312 entries for a total of 143 users. In total, 23,174 publications were analyzed.

The data collected to determine the virality and engagement of the messages created by media and journalists on TikTok (RQ2) included the number of "likes" (diggs), the number of shares, the comments, and the views.

To analyze and describe the communities created around the content produced by media and journalists (RQ3), Louvain's multilevel algorithm, commonly known as "modularity" (Blondel et al., 2008), was applied at 1-point resolution (Lambiotte; Delvenne; Barahona, 2009). The data were analyzed and processed based on the labels applied by the authors, also linking them to their engagement level. To do this, the tags used by the users in each post were first identified and an adjacency table was constructed in which each user was paired with each tag they used. Next, the adjacency table was interpreted as a bipartite (two-mode) graph, in which the nodes of mode 1 are the users and those of mode 2 are the labels. In this graph, the nodes are linked in a directed, unidirectional way, with links passing from the users to the labels. The last step was to project the two-mode graph onto a one-mode graph (Fig. 1).

This process, carried out using the NetworkX library for Python3 (Hagberg; Swart; S. Chult, 2008), produced a network of linked tags based on the users who applied them in combination. In this study, connections between labels with a value less than 2 were rejected; that is, we analyzed links between labels established by at least two users. We also removed from the sample groups of labels that were used little and were unlinked from the others.

The synthesized graph has a total of 5,638 nodes and 318,986 unique links, representing up to 790,599 weighted links between labels. All the metrics were calculated by using Gephi network analysis software.

Finally, the community most directly linked to current affairs (RQ4) was characterized based on the label use frequency.

\section{Results}

\subsection{General characteristics}

Media outlets and journalists exhibit a limited presence among the main accounts on TikTok (RQ1). None of the analyzed accounts was among the 100 accounts with the greater number of followers on this social network (Socialblade, 2021), although two sports channels (@espn and @overtime) approach this position with approximately 20 million subscribers. These are followed by three television channels aimed at children and young people: @nickelodeon, @mtv, and @inverse, being specialized in science, culture, and technology. The first account corresponding to a generalist communication medium is @dailymail. Journalists and communicators achieve more modest numbers, and only Owen Conflenti, a presenter on the Texan TV station KPRC2, reaches more than one million followers (Table 1).

In the same way as the media cannot make any headway among the accounts with the most followers, general news content also does not achieve a prominent presence on these channels. Curious or viral content with a light tone monopolizes the largest number of publications, representing work that is complementary to the main activity of the media, as demonstrated by the @dailymail account itself.

There are, however, some examples of accounts that offer current journalistic information adapted to the characteristics of the TikTok language. A good example of this is the @washingtonpost newspaper, which has more than a million followers and whose content switches between political satire and material with a didactic tone, but always with an informal and fresh tone (González-Guerra, 2020).

\begin{tabular}{|c|c|c|c|}
\hline User & Text & User & Hashtag \\
\hline user1 & $\begin{array}{l}\text { This text contains } \\
\text { \#hashtag1 and } \\
\text { \#hashtag2 }\end{array}$ & $\begin{array}{l}\text { user1 } \\
\text { user1 }\end{array}$ & $\begin{array}{l}\text { \#hashtag1 } \\
\text { \#hashtag2 }\end{array}$ \\
\hline user2 & $\begin{array}{l}\text { This text contains } \\
\text { \#hashtag2 and } \\
\text { \#hashtag3 }\end{array}$ & $\begin{array}{l}\text { user2 } \\
\text { user2 }\end{array}$ & $\begin{array}{l}\text { \#hashtag2 } \\
\text { \#hashtag3 }\end{array}$ \\
\hline user3 & $\begin{array}{l}\text { This text contains } \\
\text { \#hashtag3 and } \\
\text { \#hashtag } 4\end{array}$ & $\begin{array}{l}\text { user3 } \\
\text { user3 }\end{array}$ & $\begin{array}{l}\text { \#hashtag3 } \\
\text { \#hashtag4 }\end{array}$ \\
\hline
\end{tabular}

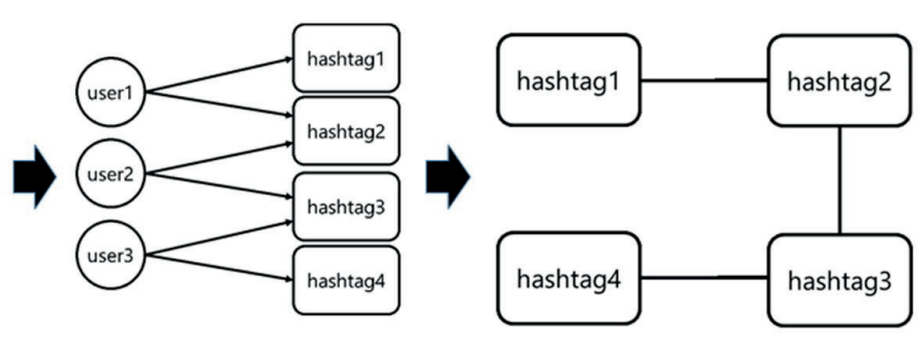

Figure 1. Analysis of labels and graphs 
Table 1. TikTok accounts with the most followers

\begin{tabular}{|l|c|c|}
\hline \multicolumn{3}{|c|}{ Top 10 media outlets with more followers } \\
\hline User & $\begin{array}{c}\text { Followers } \\
\text { (million) }\end{array}$ & $\begin{array}{c}\text { Average } \\
\text { engagements }\end{array}$ \\
\hline espn & 20.2 & $1,768,355$ \\
\hline overtime & 18.4 & $1,627,041$ \\
\hline nickelodeon & 12.2 & $245,269.87$ \\
\hline mtv & 7.7 & $2,612,924$ \\
\hline inverse & 7.0 & 391,157 \\
\hline whistle & 4.4 & 451,497 \\
\hline tnt_online & 3.7 & $1,362,000$ \\
\hline seventeen & 3.3 & 185,983 \\
\hline dailymail & 3.2 & 304,944 \\
\hline ac2alityespanol & 2.9 & 360,692 \\
\hline
\end{tabular}

\begin{tabular}{|l|c|c|}
\hline \multicolumn{3}{|c|}{ Top 10 journalists with more followers } \\
\hline User & $\begin{array}{c}\text { Followers } \\
\text { (thousand) }\end{array}$ & $\begin{array}{c}\text { Average } \\
\text { engagements }\end{array}$ \\
\hline conflenti & 1,100 & 85,496 \\
\hline taylorlorenz & 482 & 708,981 \\
\hline maxfosterenn & 422 & 758,135 \\
\hline lilia.rebrik & 288 & 453,309 \\
\hline sophiasmithgaler & 282 & 158,843 \\
\hline lizplank & 111 & 76,888 \\
\hline hannahleenews & 89 & 91,415 \\
\hline justemmawithacamera & 46 & 133,959 \\
\hline capoema & 32 & 9,617 \\
\hline aquintano & 31 & 39,478 \\
\hline
\end{tabular}

Regarding the languages used, notwithstanding the limitations caused by the sampling, the undisputed leadership of English is clear. Indeed, the accounts that produce content in this language have twenty times more followers than those that use Spanish or Russian (Table 2). In addition to its quantitative dominance, content in English demonstrates high numbers of subscribers, twice that of other languages.

Table 2. Languages used by the accounts

\begin{tabular}{|l|c|c|}
\hline \multicolumn{3}{|c|}{ Top 10 languages used by media outlets } \\
\hline User & $\begin{array}{c}\text { Followers } \\
\text { (million) }\end{array}$ & $\begin{array}{c}\text { Average } \\
\text { engagements }\end{array}$ \\
\hline English & 112.77 & 314,225 \\
\hline Russian & 6.58 & 622,047 \\
\hline Spanish & 6.18 & 243,409 \\
\hline German & 3.65 & 139,662 \\
\hline Portuguese & 1.93 & 143,434 \\
\hline French & 1.59 & 187,303 \\
\hline Italian & 1.07 & 73,102 \\
\hline Arabic & 0.24 & 256,148 \\
\hline Ukrainian & 0.21 & 29,468 \\
\hline Polish & 0.01 & 21,174 \\
\hline
\end{tabular}

\begin{tabular}{|l|c|c|}
\hline \multicolumn{3}{|c|}{ Top 10 languages used by journalists } \\
\hline User & $\begin{array}{c}\text { Followers } \\
\text { (thousand) }\end{array}$ & $\begin{array}{c}\text { Average } \\
\text { engagements }\end{array}$ \\
\hline English & 115,341 & 287,886 \\
\hline Russian & 6,582 & 622,047 \\
\hline Spanish & 6,182 & 243,409 \\
\hline German & 3,652 & 139,662 \\
\hline Portuguese & 1,932 & 143,434 \\
\hline French & 1,606 & 163,223 \\
\hline Italian & 1,098 & 63,948 \\
\hline Arabic & 497 & 182,148 \\
\hline Ukrainian & 240 & 256,148 \\
\hline Polish & 8 & 21,174 \\
\hline
\end{tabular}

\subsection{Virality and engagement}

Secondly, the analysis of the content generated by journalists and media on TikTok illustrates the great capacity of this social network to make content go viral and generate engagement among users (RQ2). During the analyzed period, the 23,174 videos shared by the 143 analyzed Table 3. Virality and engagement by account type

\begin{tabular}{|l|c|c|c|c|}
\hline \multicolumn{1}{|c|}{ User type } & Diggs & Shares & Comments & Plays \\
\hline Media outlet & 22,855 & 575 & 301 & 250,483 \\
\hline Journalist & 12,754 & 263 & 219 & 111,766 \\
\hline
\end{tabular}
accounts accumulated more than 500 million "Iikes" (diggs), were shared 12.5 million times, and generated 6.7 million comments. In total, the videos were viewed more than 5,400 billion times.

On average, each video in the sample achieved an average of 233,800 views, 21,640 "likes," 538 shares, and 291 comments. By type of account, the media obtained twice the number of views and "likes" as those of journalists, and were also shared twice as often, albeit receiving fewer comments.

Considering the media with the greatest virality and engagement, note that @espn and @overtime (both specialized in sports) stand out in all categories. This is also observed for accounts specialized in music, youth entertainment, or political news such as @mtv, @tnt_online, @nowthispolitics, and @nbcnews. Accounts related to video games and cooking recipes such as @ign and @foodnetwork also appear in the first positions. 
Table 4. Virality and engagement of the main media

\begin{tabular}{|c|c|c|c|c|c|c|c|}
\hline \multicolumn{2}{|c|}{$\begin{array}{l}5 \text { media outlets with more } \\
\text { diggs per post }\end{array}$} & \multicolumn{2}{|c|}{$\begin{array}{c}5 \text { media outlets with more } \\
\text { shares per post }\end{array}$} & \multicolumn{2}{|c|}{$\begin{array}{l}5 \text { media outlets with more } \\
\text { comments per post }\end{array}$} & \multicolumn{2}{|c|}{$\begin{array}{l}5 \text { media outlets with more } \\
\text { plays per post }\end{array}$} \\
\hline User & Diggs & User & Shares & User & Comments & User & Plays \\
\hline espn & 193,198 & overtime & 1,351 & nbcnews & 2,277 & $\mathrm{mtv}$ & 597,117 \\
\hline $\mathrm{mtv}$ & 152,931 & foodnetwork & 847 & nowthispolitics & 2,058 & espn & 405,496 \\
\hline overtime & 144,174 & nowthispolitics & 835 & overtime & 1,712 & tnt_online & 322,953 \\
\hline tnt_online & 92,810 & espn & 581 & $\mathrm{mtv}$ & 1,327 & overtime & 283,031 \\
\hline ign & 78,528 & tnt_online & 564 & espn & 1,214 & nbcnews & 163,925 \\
\hline
\end{tabular}

In the case of journalists (Table 3), three stand out in all categories: @taylorlorenz from The New York Times, @maxfostercnn from CNN, and @sophiasmithgaler from VICE. Also noteworthy are @hannahleenews from Up \& Coming Weekly (North Carolina, USA) and @liliia.rebrik, a presenter on Ukrainian television. Also, @lizplank (Vox Media and NBC News), @aquintano (photographer, NBC News, Recode, and Honolulu CB), and @capoema (an Italian freelance journalist) achieve prominent positions.

Table 5. Virality and engagement of the main journalists

\begin{tabular}{|c|c|c|c|c|c|c|c|}
\hline \multicolumn{2}{|c|}{$\begin{array}{c}5 \text { journalists with more } \\
\text { diggs per post }\end{array}$} & \multicolumn{2}{|c|}{$\begin{array}{c}5 \text { journalists with more } \\
\text { shares per post }\end{array}$} & \multicolumn{2}{|c|}{$\begin{array}{l}5 \text { journalists with more } \\
\text { comments per post }\end{array}$} & \multicolumn{2}{|c|}{$\begin{array}{c}5 \text { journalists with more } \\
\text { plays per post }\end{array}$} \\
\hline User & Diggs & User & Shares & User & Comments & User & Plays \\
\hline taylorlorenz & 99,938 & maxfostercnn & 339,192 & maxfostercnn & 2,149 & maxfostercnn & 113,471 \\
\hline maxfostercnn & 74,490 & sophiasmithgaler & 101,922 & taylorlorenz & 472 & liliia.rebrik & 53,804 \\
\hline liliia,rebrik & 22,639 & taylorlorenz & 86,686 & sophiasmithgaler & 402 & taylorlorenz & 43,122 \\
\hline sophiasmithgaler & 19,311 & lizplank & 59,316 & capoema & 137 & sophiasmithgaler & 26,333 \\
\hline hannahleenews & 12,079 & aquintano & 38,212 & hannahleenews & 118 & hannahleenews & 19,781 \\
\hline
\end{tabular}

Source: Produced with PowerBi

In general terms, the media with the most followers in turn generate the most virality and engagement. The sports channels @espn and @overtime, the music channel @mtv, and @tnt_online, a Russian channel specialized in young audiences, stand out well above their competitors. Among the accounts with a lower correspondence between followers and active following, one can mention @nickelodeon (a medium offering children's and youth content), @inverse (specialized in science and aimed at a young audience), @whistle (specialized in sports and entertainment), @seventeen (a magazine for teenagers), @dailymail (a generalist tabloid), and @ac2alityespanol (a project of the 2btube company focused on "translating" newspaper news for a teenage audience).

The professionals' accounts generally have a lower average number of followers than the media, although communicators with a significant impact can still be found on TikTok. Thus, @taylorlorenz, @maxfostercnn, and @liliiarebrik achieve substantial levels of virality and engagement.

\subsection{Hashtag communities}

To analyze the user communities created on TikTok, a graph with a total of 5,638 nodes and 318,986 unique links was synthesized, representing up to 790,599 weighted links between tags (Fig. 2). The average degree of the network is 113,275 , reflecting the average number of neighbors of each node without considering the weight of the edges. If we take weight into consideration, the weighted average degree amounts to 280,750 .

These figures suggest a high interconnection between the tags, which must be understood as a high tendency for users to use tags together on TikTok, which in turn can be interpreted as a symptom of the similarity between the different topics dealt with by users. An analysis of the network distance metrics suggests similar interpretations of the data. On average, the nodes in the network are separated by 2.19 hops, while the maximum distance is 6 hops. All these data suggest high cohesion and high interconnection in the network, reinforcing the notion of similarity.

A total of eleven communities were identified with a partition coefficient of 0.295 . This low value suggests that the identified communities are quite similar, although one can distinguish their main attributes, as described below (RQ3). Of the eleven communities detected, only eight account for more than $1 \%$ of the nodes. The other three, which represent $0.11 \%$ of the nodes, are not considered herein.

The largest community in terms of the number of users, accounting for $31.8 \%$ of the total analyzed, shares tags that are very popular on TikTok such as \#fyp or \#foryourpage, used by content creators to appear in the "For You" section of the platform and that allows them to achieve higher numbers of visits and engagement. In addition to those who seek virality on the platform, the themes that shape this community are very generic, such as \#halloween or \#christmas festivi- 
ties, or other broad subjects such as \#food, \#learnontiktok, \#music, or \#dance. In this community, the most popular accounts are @nickelodeon, @inverse, or @seventeen, all of which have a large number of followers but lower engagement figures. The weak differentiation of such content may explain this lower virality.

The second community, which accounts for $22.51 \%$ of the interactions, is the one most clearly linked to current affairs. Topics related to the pandemic such as \#covid19, \#covid, or \#vaccine share the limelight here, along with other tags such as \#news or \#climatechange. The main reference channels for this community are @ac2alityespanol, @nowthispolitics, and @yahoonews. These results reveal a significant number of followers of accounts that try to use TikTok as a channel to disseminate journalistic content adapted to the medium in a differentiated way or, at least, linked to the most popular parts of the platform. This community therefore reflects the existence of at least a small niche for following current affairs on TikTok.

Somewhat similar to the findings for community 1 , the third community (12.56\%) includes very popular tags that users expressly apply to make their content go viral, such as \#foryou, \#fy, \#tiktok, and \#viral, or generic themes that refer to content of various kinds from Covid-19 (\#corona or \#test) to \#blackfriday, \#winter, \#party, and \#lgbt. The fact that the accounts with most followers from this community include media such as @tagesschau, @sport1news, and @jornaldarecord, all of them generating content in languages other than English, illustrates the common feature of undifferentiated themes in languages different from English, similarly to the first case.

Meanwhile, entertainment and audiovisual content form the backbone of the fourth community, which accounts for $11.56 \%$ of the nodes. Tags related to audiovisual products, technology, or video games are dominant here: \#netflix, \#duet, \#gaming, \#tv, \#starwars, \#tech, or \#apple. The media most followed by this community include, e.g., @ign, @ chip_de, and @brutofficiel, all of them specialized channels, with some also sharing content in languages other than English.

Entertainment, but in this case linked to sports, shapes the fifth community (9.31\%). In this case, tags such as \#football, \#sports, or \#basketball are the distinctive elements that stand out among more generic tags associated with viral content. The accounts most followed by this community, i.e., @espn, @overtime, and @whistle, correspond to media with a clearly defined, limited, and differentiated niche, which exhibited the highest relative engagement figures in this study.

The sixth community (9.12\%) features North American musical stars for adolescent audiences such as \#travisscott, \#britneyspears, \#taylorswift, \#drake, or \#billieeilish, or the South Korean band \#bts. These tags are accompanied by other references to showbusiness such as \#metgala, \#disney, \#movie, or \#couple. The reference channels of this community of followers of the most commercial music include @mtv, @enews, and @telemundo, all with a very well-defined niche and differentiated communication. Also, as in the case of community 5, specialized content is linked to higher engagement and virality figures.

Community 7 is very small $(2.25 \%)$ and shows moderately weighted figures. In this community, general references to cinema such as \#hollywood or \#actress are prominent, particularly Indian cinema with hashtags such as \#dehli, \#bollywood, \#deepikapadukone, and \#priyankachopra. In this cluster, we also find generic hashtags such as \#trending, used with the intention of going viral, as well as references to the Indian version of the program Big Brother (i.e., \#biggboss and \#biggboss13). It is thus not surprising to find only two Indian media outlets in this community, i.e., @indianexpressent and @tims.delhitimes, which publish content essentially similar to the previous cluster but for India. This is a very small and well-differentiated cluster. The presence of this community is undoubtedly affected by the fact that India is the country with the second most Internet users, after China, which has its own version of this social network.
At least so far, there has not been a generalized commitment by news companies or professionals to generate journalistic or current affairs content on TikTok 
Finally, for the eighth community, which is even smaller than the previous one (1.38\%) and has even lower weighted figures, we only highlight the first eight labels. All of them are written in the Cyrillic alphabet and in Russian. Translated, these mean \#recomendations, its abbreviation "\#rec" (used above all to recommend audiovisual content), the teenage idols \#DanyaMilokhin, \#Kagramanov, and references to television formats such as \#Roasting or the comedy \#StandUp or the black comedy program \#QuéPasaráLuego? This community is oriented towards content about popular Russian artists, in which the reference accounts are @tnt_online, @fridaytv, and @1plus1_official. Although these media have differentiated targets, all of them are committed to entertainment based on artists and in television formats based on talent contests.

\subsection{The place of current affairs}

As seen based on these results, of the eight communities identified, which together account for more than $1 \%$ of the nodes, the first and third have a high number of publications but lower levels of virality and engagement (Table 6). Their general and nonspecialized themes seem to hinder their ability to be distributed through the network, which translates into below-average figures for all indicators, i.e., average number of views, "likes," comments, and shared content.

Meanwhile, three communities associated with entertainment content were identified, linked to audiovisual content and technology, sports, and youth music, respectively. Especially in the latter two cases, these content niches are rewarded with very high numbers of virality and engagement for their content, even tripling the average. Although smaller in size, they are characterized by a high level of activity among their followers. Such well-defined niches therefore fit perfectly with the characteristics of TikTok.

The sample is completed by two local communities (7 and 8, corresponding to India and Russia), also related to cinema, television, and entertainment, which account for more than $1 \%$ of the nodes and reach distinct levels of virality and engagement, being very high in the second case.

And what is the place of general current affairs in the case of media and journalist accounts on TikTok? Secondary, but significant (RQ4). Inspection of the results for community 2 reveals that it is the second largest with $22.51 \%$ of the nodes. In comparison, if we consider the larger communities created in this social network around the accounts of the media and journalists, we observe that the sum of the two communities that address very generalist or eminently viral issues reaches $43.94 \%$, while the remaining five, whose content lies in the fields of leisure, entertainment, and showbusiness, together include $33.45 \%$ of the nodes.

If, in contrast, we consider the capacity of news content to generate virality and engagement, we note that these publications obtain fewer views and "likes" than the average, although they are commented on and shared slightly more (Table 6).

Table 6. Virality and engagement in the communities

\begin{tabular}{|c|c|c|c|c|c|}
\hline \multicolumn{6}{|c|}{ Total engagement by community } \\
\hline Pseudo & Posts & Diggs & Shares & Comments & Plays \\
\hline 1 & 6,946 & $90,396,738$ & $3,172,690$ & $1,004,558$ & $1,067,920,610$ \\
\hline 2 & 5,257 & $98,104,604$ & $3,012,691$ & $2,568,283$ & $863,775,660$ \\
\hline 3 & 4,078 & $37,698,358$ & $1,421,229$ & 806,535 & $451,391,012$ \\
\hline 4 & 2,191 & $44,564,240$ & 844,749 & 599,153 & $391,153,131$ \\
\hline 5 & 1,319 & $92,355,355$ & $2,257,450$ & 781,055 & $910,222,597$ \\
\hline 6 & 2,157 & $100,251,415$ & $1,063,835$ & 781,935 & $1,206,710,035$ \\
\hline 7 & 241 & $2,547,425$ & 13,436 & 6,090 & $48,011,237$ \\
\hline 8 & 985 & $35,564,525$ & 670,999 & 193,698 & $478,907,942$ \\
\hline Total & 23,174 & $501,482,660$ & $12,457,079$ & $6,741,307$ & $5,418,092,224$ \\
\hline
\end{tabular}

\begin{tabular}{|c|c|c|c|c|}
\hline \multicolumn{5}{|c|}{ Mean engagements by community } \\
\hline Pseudo & Diggs & Shares & Comments & Plays \\
\hline 1 & 13,014 & 457 & 145 & 153,746 \\
\hline 2 & 18,662 & 573 & 489 & 164,310 \\
\hline 3 & 9,244 & 349 & 198 & 110,689 \\
\hline 4 & 20,340 & 386 & 274 & 178,527 \\
\hline 5 & 70,019 & 1,712 & 592 & 690,085 \\
\hline 6 & 46,477 & 493 & 363 & 559,439 \\
\hline 7 & 10,570 & 56 & 25 & 199,217 \\
\hline 8 & 36,106 & 681 & 197 & 486,201 \\
\hline Total & 21,640 & 538 & 291 & 233,801 \\
\hline
\end{tabular}




\section{Conclusions and discussion}

This analysis of the accounts of the media and journalists on TikTok reveals firstly a very limited presence of the main media outlets on this social network. At least so far, there has not been a generalized commitment by news companies or professionals to generate journalistic or current affairs content on TikTok.

This low implantation may be associated with several factors. On the one hand, the visual nature of the platform, based on very short videos and a highly specific language, makes it more difficult for media and journalists to transfer content they have generated for other platforms. In contrast to the typical use of social networks as platforms for the redistribution of informative content (Krumsvik, 2018), TikTok combines various idiosyncrasies that demand the creation of unique content adapted to its characteristics. Despite this, some media that prioritize the occupation of a virtual space on the platform as a strategy still include simple edited audiovisual fragments of their own programming, or even limit themselves to playing external viral videos on their accounts.

On the other hand, the presentation of content on the platform, posed as a continuous flow of content that is consumed in a combined, fast, and hyperfragmented way, also makes it difficult for media titles to rely on current affairs content. In certain regards, TikTok constitutes an antithetical model to the common news activity of the media that is characterized by a large amount of daily news, neutral language, and typically a textual structure. Thus, the consumption of short videos, viewed in a scattered and usually fleeting way, and using colloquial language, represents a challenge for the media, which face a greater challenge in making the leap to TikTok than that posed by their adaptation to other platforms in the past.

Second, TikTok is a platform on which the search for virality and engagement, especially with young audiences, plays a prominent role. It can be observed that the use of generic labels that seek to promote content to be shared and redistributed is a general practice also in the media, which resort to viral campaigns and memes on the web. All this results in a high rate of "likes" and of shared and commented content (Vázquez-Herrero; Negreira-Rey; Rodríguez-Vázquez, 2021).

This search for virality and presence in the continuous video streams viewed by users results in the primacy of the trivial, even in accounts belonging to media or journalists, in which brief news content coexists with content curious or challenges without journalistic value (Vázquez-Herrero; Negreira-Rey; López-García, 2020). The objective, in many cases, is more oriented toward the creation of a community of followers than the distribution of news content.

The analysis of the labels used by the media and journalists on TikTok confirms the association of this social network with content mainly related to entertainment, especially aimed at young audiences (Ballesteros-Herencia, 2020). Subjects such as sports, youth music, entertainment, movies, celebrities, and television shows find a successful niche on TikTok.

Despite this, the data obtained seem to indicate that content specialization is the key to success in this regard, since in comparison with the success of specialized accounts on specific topics, media and journalists who focus excessively on the generation of virality with an undifferentiated discourse are penalized. The consumption patterns on this platform, based on offering related content, favor specialization over generic and undefined profiles.

Finally, the data that can be extracted from the community generated around current affairs content are also interesting. On the one hand, even in the content produced by media and journalists, current affairs does not represent the majority and also does not correspond to the community with the greatest engagement capacity on this social network. However, these videos are shared slightly more and receive more comments than average, and do not lag much in terms of the views or number of "likes" they achieve.

These data suggest that there is also space on TikTok for the generation of current affairs information adapted to the characteristics of the language of this social network, which does not necessarily resort to thematic specialization or entertainment niches. A greater commitment to content created specifically for this platform may be the route to access digital natives, who usually do not expressly consume current affairs but are nevertheless exposed to a constant and broader flow of content via social networks.

\section{References}

Ahlse, Johannes; Nilsson, Felix; Sandström, Nina (2020). It's time to TikTok: Exploring Generation Z's motivations to participate in \#Challenges.

http://urn.kb.se/resolve?urn=urn:nbn:se:hj:diva-48708 
Ahmadi, Moussa; Wohn, Donghee-Yvette (2018). "The antecedents of incidental news exposure on social media". Social media + society, v. 4, n. 2, pp. 1-8.

https://doi.org/10.1177/2056305118772827

Alexander, Julia (2019). "Your guide to using TikTok". The verge, April 2.

https://www.theverge.com/2019/4/2/18201898/tiktokguide-for-you-challenge-creator-trend-algorithm-privacy

Anderson, Katie-Elson (2020). "Getting acquainted with social networks and apps: it is time to talk about TikTok". Library hi tech news, v. 37, n. 4, pp. 7-12.

https://doi.org/10.1108/LHTN-01-2020-0001

Argintzona, Jasone (2020). "Cómo ha evolucionado TikTok en España y Latinoamérica”. Digimind, 5 marzo. https://blog.digimind.com/es/tendencias/c\%C3\%B3mo-ha-evolucionado-tiktok-en-espa\%C3\%B1a-y-am\%C3\%A9rica-latina

Asarch, Steven (2018). "What is TikTok? Understanding the success of the lip-synching app". Newsweek, October 24. https://www.newsweek.com/tiktok-social-media-trending-page-hashtag-cringe-compilation-1186097

Ballesteros-Herencia, Carlos A. (2020). "La propagación digital del coronavirus: midiendo el engagement del entretenimiento en la red social emergente TikTok". Revista española de comunicación en salud, Suplemento 1, pp. 171-185. https://doi.org/10.20318/recs.2020.5459

BBC News (2020). "TikTok: la creciente preocupación por la exitosa aplicación de vídeos china". BBC News, November 8. https://www.bbc.com/mundo/noticias-50341717

Bell, Emily; Taylor, Owen (2017). The Platform Press: How Silicon Valley reengineered journalism. https://www.cjr.org/tow_center_reports/platform-press-how-silicon-valley-reengineered-journalism.php

Blondel, Vincent D.; Guillaume, Jean-Loup; Lambiotte, Renaud; Lefebvre, Etienne (2008). “Fast unfolding of communities in large networks". Journal of statistical mechanics: Theory and experiment, P1000.

https://doi.org/10.1088/1742-5468/2008/10/P10008

Boczek, Karin; Koppers Lars (2020). "What's new about WhatsApp for news? A mixed-method study on news outlets' strategies for using WhatsApp". Digital journalism, v. 8, n. 1, pp. 126-144.

https://doi.org/10.1080/21670811.2019.1692685

Boczkowski, Pablo J.; Mitchelstein, Eugenia; Matassi, Mora (2018). "News comes across when I'm in a moment of leisure": Understanding the practices of incidental news consumption on social media". New media \& society, v. 20, n. 10, pp. 3523-3539.

https://doi.org/10.1177/1461444817750396

Carlson, Matt (2020). "Journalistic epistemology and digital news circulation: Infrastructure, circulation practices, and epistemic contests". New media \& society, v. 22, n. 2. pp. 230-246.

https://doi.org/10.1177/1461444819856921

Cervi, Laura; Marín-Lladó, Carles (2021). "What are political parties doing on TikTok? The Spanish case". Profesional de la información, v. 30, n. 4, e300403.

https://doi.org/10.3145/epi.2021.jul.03

Chadwick, Andrew (2013). The hybrid media system: Politics and power. Oxford: Oxford University Press. ISBN: 978 0 190696733

Dodds, Tomás (2019). "Reporting with WhatsApp: Mobile chat applications' impact on journalistic practices". Digital journalism, v. 7, n. 6, pp. 725-745. https://doi.org/10.1080/21670811.2019.1592693

Eldridge, Scott A.; Hess, Kristy; Tandoc, Edson C.; Westlund, Oscar (2019). "Navigating the scholarly terrain: Introducing the digital journalism studies compass". Digital journalism, v. 7, n. 3, pp. 386-403.

https://doi.org/10.1080/21670811.2019.1599724

García-Avilés, José-Alberto; Arias-Robles, Félix (2016). "Géneros periodísticos en los formatos visuales de Twitter". Textual \& visual media: Revista de la Sociedad Española de Periodística, n. 9, pp. 101-132.

https://textualvisualmedia.com/index.php/txtvmedia/article/view/52

González-Guerra, Florencia (2020). “¿Qué están haciendo los medios latinoamericanos en TikToK?”. Wan-IFRA, February 27. https://blogarchive.wan-ifra.org/2020/02/27/que-estan-haciendo-los-medios-latinoamericanos-en-tiktok

Hagberg, Aric; Swart, Pieter; S. Chult, Daniel (2008). "Exploring network structure, dynamics, and function using Networkx". In: Proceedings of the $7^{\text {th }}$ Python in science conference (SciPy2008), pp. 11-15.

https://www.osti.gov/servlets/purl/960616 
Han, Yu (2020). "Advertisement on Tik Tok as a pioneer in new advertising era: Exploring its persuasive elements in the development of positive attitudes in consumers". The frontiers of society, science and technology, v. 2, n. 11, pp. 81-92. http://doi.org/10.25236/FSST.2020.021113

Henneman, Todd (2020). "Beyond lip-synching: Experimenting with TikTok storytelling". Teaching journalism \& mass communication, v. 10, p. 2, pp. 1-14.

https://www.proquest.com/docview/2523169901

Hermida, Alfred (2016). "Social media and the news". In: Witschge, Tamara; Anderson, C. W.; Domingo, David; Hermida, Alfred. The SAGE handbook of digital journalism, pp. 81-94. ISBN: 9781473906532

https://doi.org/10.4135/9781473957909

Herrman, John (2019). "How TikTok is rewriting the world". The New York Times, March 10. https://www.nytimes.com/2019/03/10/style/what-is-tik-tok.html

Klinger, Ulrike (2013). “Mastering the art of social media”. Information, communication \& society, v. 16, n. 5, pp. 717-736. https://doi.org/10.1080/1369118X.2013.782329

Krumsvik, Arne H. (2018). “Redefining user involvement in digital news media”. Journalism practice, v. 12, n. 1, pp19-31. https://doi.org/10.1080/17512786.2017.1279025

Labio-Bernal, Aurora (2008). "Periodismo de entretenimiento: La trivializacion de la prensa de referencia". Estudios sobre el mensaje periodístico, n. 14, pp. 435-447.

https://revistas.ucm.es/index.php/ESMP/article/view/ESMP0808110435A

Lambiotte, Renaud; Delvenne, Jean-Charles; Barahona, Mauricio (2009). “Dynamics and multiscale modular structure in networks". arXiv:0812.1770, pp. 1-29.

https://arxiv.org/abs/0812.1770

López-de-Ayala, María-Cruz; Vizcaíno-Laorga, Ricardo; Montes-Vozmediano, Manuel (2020). “Hábitos y actitudes de los jóvenes ante las redes sociales: influencia del sexo, edad y clase social”. Profesional de la información, v. 29, n. 6, e290604

https://doi.org/10.3145/epi.2020.nov.04

Medina-Serrano, Juan-Carlos; Papakyriakopoulos, Orestis; Hegelich, Simon (2020). "Dancing to the partisan beat: A first analysis of political communication on TikTok". In: $12^{\text {th }}$ ACM conference on web science, pp. 257-266.

https://doi.org/10.1145/3394231.3397916

Negreira-Rey, María-Cruz; López-García, Xosé; Lozano-Aguiar, Lara (2017). “Instant messaging networks as a new channel to spread the news". In: Rocha, Álvaro; Correia, Ana-María; Adeli, Hojjat; Reis, Luis-Paulo; Costanzo, Sandra. Recent advances in information systems and technologies. WorldCIST 2017. Advances in intelligent systems and computing, $\mathrm{v}$. 571, pp. 64-72. Cham: Springer. ISBN: 9783319565408

https://doi.org/10.1007/978-3-319-56541-5_8

Ostrovsky, Adam M.; Chen, Joshua R. (2020). "TikTok and its role in Covid-19 information propagation". Journal of adolescent health, v. 67, n. 5, p. 730.

https://doi.org/10.1016/j.jadohealth.2020.07.039c

Pavlik, John (2019). Journalism in the age of virtual reality: How experiential media are transforming news. New York: Columbia University Press. ISBN: 9780231184496

Peña-Fernández, Simón; Lazkano-Arrillaga, Iñaki; García-González, Daniel (2016). “European newspapers' digital transition: New products and new audiences". Comunicar, n. 46, pp. 27-36.

https://doi.org/10.3916/C46-2016-03

Pew Reserch Center (2021). Social media use in 2021.

https://www.pewresearch.org/internet/2021/04/07/social-media-use-in-2021

Rashidian, Nushin; Civeris, George; Brown, Pete; Bell, Emily; Hartstone, Abigail (2020). Platforms and publishers: The end of an era.

https://www.cjr.org/tow_center_reports/platforms-and-publishers-end-of-an-era.php\#conclusion

Sánchez-Castillo, Sebastián; Mercado-Sáez, María-Teresa (2021). "Sufro una grave enfermedad rara. Reto a cantar y hacer coreografías en TikTok". Profesional de la información, v. 30, n. 4, e300414.

https://doi.org/10.3145/epi.2021.jul.14

Shearer, Elisa (2018). Social media outpaces print newspapers in the U.S. as a news source.

https://www.pewresearch.org/fact-tank/2018/12/10/social-media-outpaces-print-newspapers-in-the-u-s-as-a-newssource 
Sidorenko-Bautista, Pavel; Herranz-de-la-Casa, José-María; Cantero-de-Julián, Juan-Ignacio (2020). “Use of new narratives for Covid-19 reporting: From 360 videos to ephemeral TikTok videos in online media”. Trípodos, v. 1, n. 47, pp. 105-122.

https://doi.org/10.51698/tripodos.2020.47p105-122

Socialblade (2021). Top100 most followed TikTok accounts.

https://socialblade.com/tiktok/top/100

Spyridou, Lia-Paschalia; Matsiola, María; Veglis, Andreas; Kalliris, George; Dimoulas, Charalampos (2013). “Journalism in a state of flux". International communication gazette, v. 75, n. 1, pp. 76-98.

https://doi.org/10.1177/1748048512461763

Statista (2020). TikTok- Statistics \& facts.

https://www.statista.com/topics/6077/tiktok

Statista (2021). Most popular social networks worldwide as of January 2021, ranked by number of active users.

https://www.statista.com/statistics/272014/global-social-networks-ranked-by-number-of-users

Steensen, Sten; Westlund, Oscar (2020). What is digital journalism studies? London: Routledge. ISBN: 9780367200909

Sveningsson, Malin (2015). "'It's only a pastime, really': Young people's experiences of social media as a source of news about public affairs". Social media + society, v. 1, n. 2.

https://doi.org/10.1177/2056305115604855

Valerio-Ureña, Gabriel; Herrera-Murillo, Dagoberto J.; Villanueva-Puente, Fernando; Herrera-Murillo, Natalia; Rodríguez-Martínez, María-del-Carmen (2015). "The relationship between post formats and digital engagement: A study of the Facebook pages of Mexican univerisities". RUSC. Universities and knowledge society journal, v. 12, n. 1, pp. 50-63.

https://repositorio.tec.mx/ortec/handle/11285/611834

Vázquez-Herrero, Jorge; Direito-Rebollal Sabela; Lopez-García, Xosé (2019). “Ephemeral journalism: News distribution through Instagram stories". Social media + society, v. 5, n. 4, pp. 1-13.

https://doi.org/10.1177/2056305119888657

Vázquez-Herrero, Jorge; Negreira-Rey, María-Cruz; López-García, Xosé (2020). “Let’s dance the news! How the news media are adapting to the logic of TikTok". Journalism.

https://doi.org/10.1177/1464884920969092

Vázquez-Herrero, Jorge; Negreira-Rey, María-Cruz; Rodríguez-Vázquez, Ana-Isabel (2021). "Intersections between TikTok and TV: Channels and programmes thinking outside the box". Journalism and media, v. 2, n. 1, pp 1-13.

https://doi.org/10.3390/journalmedia2010001

Vector ITC (2020). Digital trends 2020.

https://softtek.eu/wp-content/uploads/2018/06/2020-Digital-Trends.pdf

Wahl-Jorgensen, Karin (2020). “An emotional turn in journalism studies?”. Digital journalism, v. 8, n. 2, pp. $175-194$. https://doi.org/10.1080/21670811.2019.1697626

Wang, Yu-Huan; Gu, Tian-Jun; Wang, Shyang-Yuh (2019). "Causes and characteristics of short video platform internet community taking the TikTok short video application as an example". 2019 IEEE International conference on consumer electronics.

https://doi.org/10.1109/ICCE-TW46550.2019.8992021

Welbers, Kasper; Opgenhaffen, Michaël (2019). “Presenting news on social media”. Digital journalism, v. 7, n. 1, pp. 45-62.

https://doi.org/10.1080/21670811.2018.1493939

Wu, Shangyuan; Tandoc, Edson C.; Salmon, Charles T. (2019). "Journalism reconfigured”. Journalism studies, v. 20, n. 10, pp. 1440-1457.

https://doi.org/10.1080/1461670X.2018.1521299

Zaffarano, Francesco (2021). "Here's a running list of publishers and journalists on TikTok". Niemanlab, Octuber 10. https://www.niemanlab.org/reading/heres-a-running-list-ofpublishers-and-journalists-on-tiktok

Zelizer, Barbie (2019). "Why journalism is about more than digital technology". Digital journalism, v. 7, n. 3, pp. 343-350. https://doi.org/10.1080/21670811.2019.1571932 